\title{
Hybrid Photovoltaic-Thermal Collectors: A Review
}

\author{
Figueiredo Ramos ${ }^{1}$, António Cardoso ${ }^{2}$, and Adérito Alcaso ${ }^{1}$ \\ ${ }^{1}$ Polytechnic Institute of Guarda, School of Technology and Management, Portugal \\ \{framos, aderitona\} @ipg.pt \\ ${ }^{2}$ University of Coimbra, FCTUC/IT, Department of Electrical \\ and Computer Engineering, Portugal \\ ajmcardoso@ieee.org
}

\begin{abstract}
Solar energy can be converted directly into electric and thermal energy through photovoltaic cells and thermal collectors, respectively. However this conversion, in particular the photovoltaic, has a reduced efficiency. A solution proposed to increase this efficiency is with the hybrid solar structure, which consists in the junction of the photovoltaic panel and the thermal collector in a single module. The interest on these solar systems led the International Energy Agency to create a "Task" on this subject. This paper presents a review of the research in this area, presenting the definitions of the related collectors and results of their characteristics, as well as some ideas for future studies.
\end{abstract}

Keywords: Hybrid photovoltaic/thermal (PV/T) collector, photovoltaic (PV), thermal (TH), heat transfer, efficiency.

\section{Introduction}

At the beginning of the XXI century the energy issues have been occupying a central place in the international concerns. These concerns are related to ecological aspects, namely climatic concerns with the global heating and climate changes, economic aspects, tied to the scarcity of resources of fossil origin and geopolitical aspects, regarding the difficulty of energy transportation mainly through politically unstable zones.

Due to the vital importance of the energy sector in the countries economies and from all the issues mentioned above, it is necessary to establish new energy and environmental politics in order to find a balance between the environmental, technical and economical viability of energy production and consumption, promoting thus a sustainable development.

The European Union (EU), geographic area that is strongly dependent on external primary energy, considers that, relatively to the energy sources, a strong increase of renewable energies in global energy production is desirable, in order to reach a $15 \%$ contribution until 2010. The concerns of the EU on energy and environmental politics integration are reported in the new "Energy Politics for the Europe". This politic proposal must be the basic instrument for the reduction of the Greenhouse Gases and the increment of the energy production with renewable sources, among others. Also in Portugal, the Government has defined the "National Strategy for the Energy" to promote energy production on the basis of renewable sources, with the capacity of exploration in the country, being the solar energy one of them. 
The technology associated with the exploitation of solar energy, namely the independent photovoltaic and thermal systems, for conversion of the solar radiation into electric and thermal energy, respectively, is already a mature technology. However, one of the inconveniences associated to this traditional technology, particularly the photovoltaic one, is its low efficiency, leading necessarily to great areas of implantation for these systems, which is a major limitation. That is particularly important in applications where the availability of free lands is more limited. Moreover, the solar radiation increases the temperature of photovoltaic cells, decreasing their efficiency, and the natural convection cooling of these modules, due to climatic conditions, is not enough to reduce the temperature in order obtain a desired maximal efficiency. To surpass these inconveniences, investigators had considered the integration of the thermal and photovoltaic systems in a single device for conversion of solar energy with simultaneous production and consumption of electric and thermal energy. The goal of this integration is to generate more energy per unit area than with the photovoltaic panel and the thermal collector, installed independently. These devices of solar co-generation are called "Photovoltaic-Thermal" collectors/panels or "PV/T". In contrast to the independent photovoltaic and thermal solar systems, the hybrid devices have not reached yet a technological maturity and are still being studied. By recognizing their potentialities, the International Energy Agency has created a task, "Task 35 - Solar PV/Thermal Systems", whose aim is to increase the common knowledge of the PV/T solar systems, the promotion of their development, the market introduction of these solar systems with quality and commercial competitiveness and also contributing to the standardization of functional tests and surveillance of commercial characteristics of these systems in the construction sector. Under supervision of Task 35 some publications were developed [1-3] being foreseen for publication in 2009 a final report, with the goal of presenting all the information about the $\mathrm{PV} / \mathrm{T}$ solar systems.

\section{Contribution to Technological Innovation}

In this paper, a review of the research on $\mathrm{PV} / \mathrm{T}$ collectors and their application in heat and electricity production will be presented, illustrating their potentialities.

The performance of PV/T collectors depends on many variables, being the temperature one of the most important, and, although promising, there is not yet a consensus about the viability of this technology and its application, since it can differs from region to region. For example, in the northern countries, with lesser solar radiation, the PV/T collectors can be used, to a large extent, integrated in buildings to lower the temperature of the PV modules and to supply hot air for preheating of interior spaces. In countries with warmer climate, as it is the case of the Mediterranean countries, the PV/T collectors can be used, for the most part, to lower the temperature of PV modules and heating domestic waters.

More research is needed, namely regarding modelling, structure dimensioning and topology aspects. A setup is being developed in order to experimentally validate this research, which will also comprises a modelling and computational simulation based on techniques of distributed parameters and finite elements, in order to obtain a better temperature distribution in the $\mathrm{PV} / \mathrm{T}$. 


\section{PV/T Collector Types}

Different possibilities are described in the literature for the construction of a PV/T. The basic structure uses a thermal fluid for cooling photovoltaic cells, allowing the increase of their conversion efficiency and recovering some of the various heat losses that in another way would be simply transmitted to the environment. This allows the production of thermal energy and its direct application in domestic water heating, swimming pools or drying substances, among others.

The PV/T collectors can be classified primarily with regard to the existence, or not, of auxiliary mechanisms for concentration of the solar radiation. The collectors with concentrators use reflective devices in order to increase the amount of solar radiation in a small area (in the PV face). The collectors without concentrators are of flat type, like usual PV panels, and the solar radiation directly reaches the area of the collector. The collectors are still classified in accordance with the existence of a solar tracking system and the type of thermal fluid that can either be liquid (water) or gas (air).

Regarding the concentrating type, some authors [4], [5] had developed PV/T collectors that consist of a parabolic reflective surface that concentrates more solar energy in the photovoltaic cells, whose material must support the high working temperatures of these collectors in the receiving area. In the backs of the photovoltaic arrangement, the thermal fluid (normally water with antifreezing characteristics) cools the PV cell taking out the heat for the production of thermal energy. Other authors [6] developed a structure with a different version of concentrating PV/T, as shown in Fig. 1 , with a system composed by two parabolic mirrors. In this system, that must include a solar tracker, the first mirror concentrates the solar radiation of small wavelength in photovoltaic cells for production of electric energy, whereas the second parabolic receives the radiation with higher wavelength that however crossed the first mirror and that later will be reflected in a pipe that has a fluid in its interior, that serves as a way of thermal transference. This system, according to its authors, proved to be efficient and economically competitive as compared to the traditional power plants.

With respect to flat-type PV/T collectors, more often used than the concentrating ones, these are similar to common thermal collectors and photovoltaic panels, which are cheaper although less efficient. The flat PV/T collector is usually constituted by the PV component, whose material is the conventional doped crystalline silicon, and the TH component, joined each other, being the later behind the first one. This PV/T module can be glassed or not, i.e. it can include or not, in its structure, a glass placed above the photovoltaic cells.

Fig. 2 shows the structure of a typical flat plate PV/T collector showing the PV module, the heat extraction equipment - metallic plate constituted by pipes that absorb heat and functions as a cooling system of the PV module attached to it - the glass cover and the thermal isolation that has a function of preventing great heat losses through the equipment walls. These collectors are suitable for roof installation or other areas of easy access, not only because they allow an easy and adjusted integration in constructions, but also because they occupy less space than the photovoltaic and thermal modules used separately. 


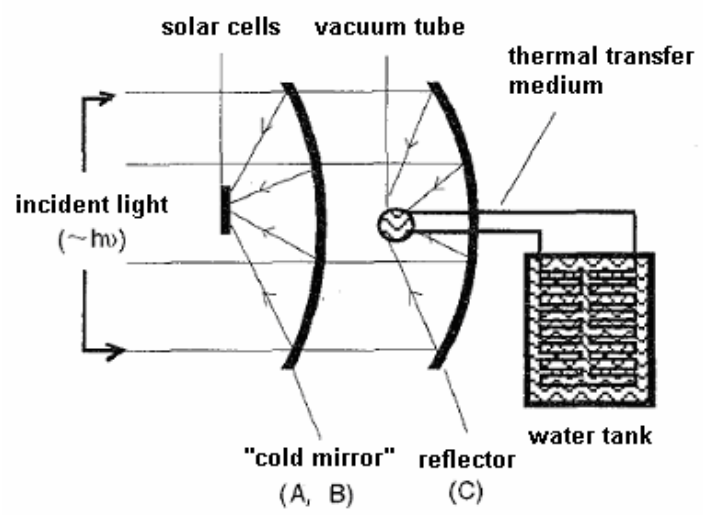

Fig. 1. A schematic structure of a concentrating PV/T collector [6]

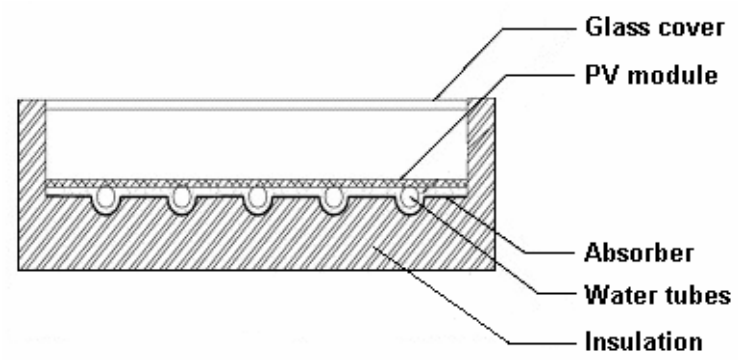

Fig. 2. Cross section of a flat plate PV/T collector

The flat plate PV/T collectors can be divided in two types: water and air, depending on what fluid passes through the pipes. When using water it is usually associated to another liquid with antifreezing characteristics, so that it does not freeze so easily when the environment reaches negative temperatures, preventing damages in the system. According to the typical PV/T collector shown on Fig.2, there are authors [7], [8] that propose the air as a thermal fluid, showing that for the same amount of solar radiation, the efficiency of the photovoltaic module is always lower than the thermal module and also that the increase of solar radiation results in an increase of the efficiency of the two modules, PV and TH.

Other authors [9-12] analysed a PV/T collector with water as thermal fluid and multicrystaline silicon PV panel, with and without a glass cover. They had stated that using this cover in a collector increases the thermal efficiency, but reduces the electric efficiency due to the additional losses by reflection. These authors also consider the choice of the thermal fluid as one of the most important selections to make, having the liquid ones (water) a better performance than the air collectors.

The evaluation of the PV/T systems and their application areas are analyzed in [13]. The authors consider that thanks to the use of PV/T collectors, which they call as solar co-generation technology, there are some practical and technical improvements regarding the installation of $\mathrm{PV}$ and $\mathrm{TH}$ systems separately. These improvements are: 
a lesser installation area, reduced installation costs and the fact that PV and TH modules use different parts of the solar spectrum (PV - wavelength of the visible one; $\mathrm{TH}$ - wavelength of the infrared one), making the flat PV/T hybrid technology well adjusted to explore both radiations, due to the fact that the silicon, main component used in the PV cells, is partially transparent to the infrared radiation. It is important that the $\mathrm{PV} / \mathrm{T}$ collector absorbs the maximum radiation that it receives, using for this a good $\mathrm{PV}$ and a thermal plate with a great absorption of heat.

\section{PV/T Collectors Performance}

A realistic system for the simultaneous conversion of the solar radiation in electric and thermal energy through the PV/T is schematized in Fig. 3. Apart from the PV/T collector, that converts the solar radiation, the system includes a possible pump and hot water storage for the thermal system, and a charge controller, a battery and a $\mathrm{DC} / \mathrm{AC}$ converter, for the electric system. There is also a supervision and control system of the conversion process.

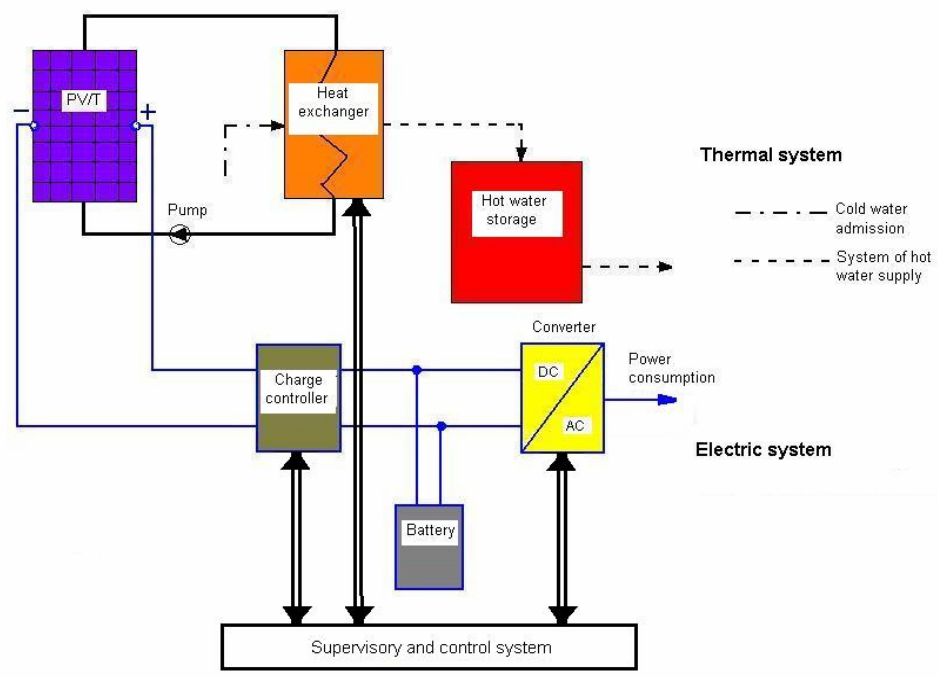

Fig. 3. Block diagram of PV/T system

The performance of PV/T system depends on factors like the temperature of the thermal fluid, the amount of the mass flow of this fluid, the number of glass covers, the configuration of the thermal flat plate module and the supervisory and control system.

In the analysis of a PV/T collector [14] it was reported that the reduction of the temperature verified in PV module, due to the thermal fluid, was superior to $10{ }^{\circ} \mathrm{C}$ which implied an increase of about $5 \%$ in the photovoltaic efficiency.

As stated before, in a flat PV/T collector without additional glass cover the electric efficiency is bigger than with a covering glass. In this case the PV module can even 
reach a bigger temperature than a conventional PV panel and there is an increase of reflected radiation on the top of the collector. To reduce the verified reflection the glass cover must be highly transparent to the solar radiation [15].

When the thermal resistance between PV and TH modules increases, this implies the existence of a great difference in temperatures - high temperature gradient - between them, leading to the increase of thermal losses and a reduction of PV performance. In PV/T collectors the thermal efficiency increases with increased heat transfer coefficients, that is, with the reduction of thermal resistance. With glass covers the thermal efficiency of the collector is bigger.

\section{Modelling and Simulation}

The modelling of a PV/T system can be based on the known base models of the PV and TH modules, with an additional path between them. The model can then be implemented in a software package. The majority of studies used the TRNSYS (The Transient Energy System Simulation Tool) simulation program or the MATLAB/SIMULINK. TRNSYS was initially developed only for thermal systems but has been also applied to PV/T collectors with electrical systems. In [16 ] a simulation was presented considering meteorological data of a typical year of the city of Nicosia, Cyprus. The goal of this study was the optimization of the water flow in the system. In [17] different PV/T systems had been analysed with TNRSYS, namely for the cases of water heating in a house and preheat of the ventilation air in a school. The simulation was executed by a period of one year, with typical climatic data from Holland. For the areas of research and development TRNSYS is used significantly when the simulation is focused in TH part, even though the simulation environment also allows the inclusion of PV models, [18], [19]. Fig. 4 shows a TRNSYS model used to simulate a PV/T solar window [20].

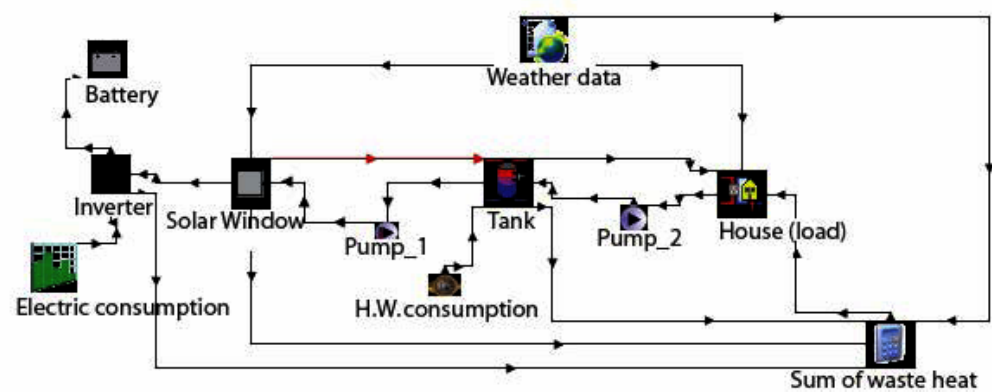

Fig. 4. Block diagram of a PV/T TRNSYS model [21]

In [21] a PV/T system was analysed, in this case, with MATLAB/SIMULINK and the obtained results were compared with the experimental ones, concluding that the considered system was possible, although needing more research. 


\section{Conclusions}

This work has presented a review of the available literature on PV/T collectors, mainly of flat plate type. The results show that the PV/T efficiency is sensitive to many variables and a more detailed study seems to be necessary in order to obtain an optimal PV/T collector with improved efficiency and reduced costs, in order to be economically competitive.

Acknowledgement. This work was supported in part by the Portuguese Foundation for Science and Technology (FCT) under Project N ${ }^{\circ}$ SFRH/BD/50276/2009 and Project No SFRH/BSAB/950/2009.

\section{References}

1. PV/T Collectors: Technologies Combine to Increase Output. IEA SHC Solar Update Newsletter, Document Number DE2-4 (2006)

2. Hansen, J., Sorensen, H.: IEA SHC Task 35 PV/Thermal Solar Systems. World Renewable Energy Congress, Document Number DE2-3, Firenze, Italy (2006)

3. Zondag, H.A.: Commercially Available PV/T Products. Document Number DA2-1 (2006)

4. Coventry, J.S.: Performance of a Concentrating Photovoltaic/Thermal Solar Collector. Solar Energy 78, 211-222 (2005)

5. Smeltink, J.F.H., Blakers, A.W.: 40 kW PV Thermal Roof Mounted Concentrator System. In: 4th World Conference on Photovoltaic Energy Conversion, Waikoloa, HI (2006)

6. Yang, M., Izumi, H., Sato, M., Matsunaga, S., Takamoto, T., Tsuzuki, K., Amono, T., Yamaguchi, M.: A 3kW PV-Thermal System for Home Use. In: Twenty-Sixth IEEE Photovoltaic Specialists Conference, Anaheim, CA (1997)

7. Bhargava, A.K., Garg, H.P., Agarwal, R.K.: Study of a Hybrid Solar System - Solar Air Heater Combined with Solar Cells. Energy Convers. Mgmt. 31(5), 471-479 (1991)

8. Aste, N., Beccali, M., Chiesa, G.: Experimental Evaluation of the Performance of a Prototype Hybrid Solar Photovoltaic-Thermal (PV/T) Air Collector for the Integration in Sloped Roof. In: Proceedings of EPIC 2002 AIVC, Lyon, France (2002)

9. Tripanagnostopoulos, Y., Souliotis, M., Battisti, R., Corrado, A.: Application Aspects of Hybrid PV/T Solar Systems. In: ISES Solar World Congress, Goteborg, Sweden (2003)

10. Zondag, H.A., van Helden, W.G.J., Elswijk, M.J., Bakker, M.: PV-Thermal collector development - an overview of the lessons learnt. In: 19th European PV Solar Energy Conference and Exhibition, Paris, France (2004)

11. Zondag, H.A., Jong, M.J.M., Helden, W.G.J.: Development and Applications for PV Thermal. In: 17th European Photovoltaic Solar Energy Conference, Munchen, Germany (2001)

12. Zondag, H.A., van Helden, W.G.J.: PV-Thermal Domestic Systems. In: 3rd World Conference on Photovoltaic Energy Conversion, Osaka, Japan (2003)

13. Elia, S., Tiberi, V.: Dimensioning and Efficiency Evaluation of Hybrid Solar Systems for Energy Production. Thermal Science 12(3), 127-138 (2008)

14. Vandaele, W.P., Bloem, J.J., Zaaiman, W.J.: Combined heat and power from hybrid photovoltaic building integrated components: results from overall performance assessment. In: 2nd World Conference and Exhibition on Photovoltaic Energy Conversion, Wien (1998)

15. Furbo, S., Shah, J.J.: Solar Energy 74, 513-523 (2003) 
16. Kalogirou, S.A.: Use of TRNSYS for modelling and simulation of a hybrid PV-thermal solar system for Cyprus. Renewable Energy 23, 247-260 (2001)

17. Jong, M.J.M.: System Studies on Combined PV/Thermal Panels. In: Elftes Symposium Thermisch Solarenergie, Germany (May 2001)

18. Energia Solar Térmica - Manual Sobre Tecnologias, Projecto e Instalação. Comissão Europeia, programa ALTENER (2004)

19. Energia Fotovoltaica - Manual Sobre Tecnologias, Projecto e Instalação. Comissão Europeia, programa ALTENER (2004)

20. Davidsson, H., Perers, B., Karlsson, B.: Performance of a multifunctional PV/T Hybrid Solar Window. Passivhus Norden, Trondheim (2008)

21. Járdán, R.K., Nagy, I., Barabás, R.: Control of a Combined Photovoltaic/Thermal Energy System. In: ICIT 2003, Maribor, Slovenia (2003) 